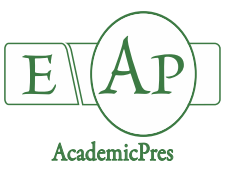

Meguekam TL et al. (2021)

Notulae Botanicae Horti Agrobotanici Cluj-Napoca

Volume 49, Issue 1, Article number 12049

DOI: $10.15835 /$ nbha49112049

Research Article

\title{
Changes in plant growth, leaf relative water content and physiological traits in response to salt stress in peanut (Arachis hypogaea L.) varieties
}

\author{
Tekam L. MEGUEKAM ${ }^{1}$, Dany P. MOUALEU ${ }^{2}$, \\ Victor D. TAFFOUO ${ }^{3 *}$, Hartmut STÜTZEL ${ }^{2}$ \\ ${ }^{1}$ University of Yaounde I, Higher Teacher Training College, Department of Biological Sciences, P.O. Box 47 Yaounde, \\ Cameroon; fmeguekame@yahoo.fr \\ ${ }^{2}$ Leibniz University, Institute of horticultural Production Systems, Department of Modeling of Vegetable Systems, 30419 Hannover, \\ Germany;moualeu@gem.uni-hannover.de; stuetzel@gem.uni-hannover.de \\ ${ }^{3}$ University of Douala, Department of Botany, Faculty of Sciences, P.O. Box 24157 Douala, \\ Cameroon;dtaffouo@univ-douala.com ("corresponding author)
}

\begin{abstract}
Salinity is the main environmental factor accountable for decreasing crop productivity worldwide. The effects of $\mathrm{NaCl}$ salinity on plant growth (leaf relative water content (RWC), leaf dry weight (LDW), shoot length (SL), number of leaves (NL), number of branches (NB) and total leaf area (TLA) and physiological characteristics (stomatal conductance $\left(\mathrm{g}_{\mathrm{s}}\right)$, transpiration rate $(\mathrm{TR})$, net photosynthetic $\left(\mathrm{P}_{\mathrm{n}}\right)$, yield of photosystem II (ФPsII) and the intercellular $\mathrm{CO}_{2}$ concentration $\left(\mathrm{CO}_{\text {2int }}\right)$ in peanut (Arachis hypogaea L.) varieties ('Vanda', 'P244601' and 'Pl184948', widely used in Cameroon, Tanzania and Ghana, respectively, were investigated under hydroponic condition. Plants were subjected to four levels of $\mathrm{NaCl}(0,40,80$ and $120 \mathrm{mM})$ at early seedling growth stage of plant development. Application of $\mathrm{NaCl}$ treatment led to a significant decrease in LDW, SL, NL, TLA, $\mathrm{P}_{\mathrm{n}}, \mathrm{g}$, TR and $\mathrm{CO}_{\text {2int }}$ concentration of 'Vanda' and 'P244601' compared to untreated plants while the plant growth inhibition was notably noted at $120 \mathrm{mM} \mathrm{NaCl}$ in 'P1184948' for LDW, SL and NB. The highest depressive effect was detected in $\mathrm{g}_{\text {s }}$ of salt-sensitive 'Vanda' while the lowest were recorded in $\mathrm{g}_{s}$ of salt-tolerant 'P1184948' at high salinity level. Enhanced $\mathrm{NaCl}$ concentrations led to a significant increase in ФPSII of 'P1184948' compared to 'Vanda', 'P244601' and untreated plants. Leaf CHL content was significantly increased in moderately-tolerant 'P244601' and salt-tolerant 'P1184948' at $80 \mathrm{mM} \mathrm{NaCl}$ compared to salt sensitive 'Vanda' and untreated plants. The depressive effect of salt on RWC was recorded at $120 \mathrm{mM} \mathrm{NaCl}$ in peanut leaves of all varieties. Under salt stress 'P1184948' was observed to have relatively higher tolerance on average of all growth and physiological traits than 'Vanda' and P244601' suggesting that it could be grown in salt-affected soils.

Keywords: hydroponic condition; plant growth; physiological traits; peanut; salinity

Abbreviations: calcium-Ca; chloride-Cl; chlorophyll-CHL; days after sowing-DAS; intercellular $\mathrm{CO}_{2}$ concentration- $\mathrm{CO}_{2 \text { int; }}$ leaf dry weight-LDW; magnesium-Mg; net photosynthetic- $\mathrm{P}_{\mathrm{n}}$; nitrogen-N; number of leaves-NL; number of branches-NB; phosphorus-P ; potassium-K ; relative water content-RWC; shoot length-

Received: 23 Aug 2020. Received in revised form: 30 Oct 2020. Accepted: 02 Dec 2020. Published online: 05 Jan 2021.

From Volume 49, Issue 1, 2021, Notulae Botanicae Horti Agrobotanici Cluj-Napoca journal will use article numbers in place of the traditional method of continuous pagination through the volume. The journal will continue to appear quarterly, as before, with four annual numbers.
\end{abstract}


SL; sodium-Na; stomatal conductance- $\mathrm{g}_{s,}$ total leaf area-TLA; transpiration rate-TR; yield of photosystem IIФPsII.

\section{Introduction}

Salinity is the main environmental factor accountable for decreasing crop productivity in many areas of the world especially in arid and semi-arid regions (Turan et al., 2007; Mirza et al., 2019). Salinity reduces growth and yield of the non-halophytes plants by decreasing the availability of water to the roots due to the osmotic effect of external salt and by toxic effects of excessive salt accumulation within the plant (Munns et al., 2006; Munns and Gilliham, 2015). The detrimental effects of salt on plants are the consequence of both a water deficit that results from the relatively high solute concentrations in the soil as well as a stress specific to $\mathrm{Cl}$ and $\mathrm{Na}$, resulting in a wide variety of physiological and biochemical changes that inhibit plant growth and development and disturb photosynthesis, respiration, protein synthesis and nucleic-acid metabolism (Sairam et al., 2002; Negrão et al., 2017). $\mathrm{P}_{\mathrm{n}}, \mathrm{TR}, \mathrm{g}_{\mathrm{s}}$ and $\mathrm{CO}_{2 \text { int }}$ concentration are all affected strongly by saline conditions (Sobrado, 1999; Turan et al., 2007; Mekhaldi et al., 2008) and the changes in $P_{n}$ may result from the closure of stomata induced by osmotic stress, or from salt damaging of photosynthesic apparatus or other metabolic processes (Negrão et al., 2017). ФPsII is also reflect the damages to photosynthetic apparatus under the salt stress (Ashraf and Harris, 2013; Chen et al., 2015).

The responses of plants to high soil salinity and the mechanisms of salt tolerance have been discussed in many works published (Meguekam et al., 2014; Nouck et al., 2016; Taffouo et al., 2017; Hniličková et al., 20017). Under salt stress, plants have evolved complex mechanisms allowing for adaptation to osmotic and ionic stress caused by high salinity. These mechanisms include osmotic adjustment by accumulation of compatible solutes such as soluble sugar, proline, glycine betaine, and soluble protein (Turan et al., 2007; Xu et al., 2009; Meguekam et al., 2014). However, an active antioxidative defense system comprising enzymatic such as peroxidase and superoxide dismutase (Waterman and Mole, 1994; Taffouo et al., 2017) and non-enzymatic antioxidants as well as flavonoids and phenolic compounds reduce the level of oxidative stress in plant cells by scavenging free radicals (Ashraf, 2009; Azooz et al., 2009; Abogadallah et al., 2010). In case of high salinity, oxidative stress occurs due to closure of stomata, interruption of photosynthetic electron transport and disruption of cellular membrane integrity and antioxidative defence systems of plants start work against oxidative damage (Sairam et al., 2002; Mehr et al., 2012). Water deficit causes a leaf turgor decrease, further causing stomata closure and decreases of stomatal conductance; one of the factors limiting net photosynthesis (Chaves et al., 2009). Salt stress reduced the relative water content (RWC) in two wheat cultivars, 'Giza 168' and 'Gimeza 9', the reduction was more pronounced in 'Giza 168' (El-Bassiouny and Bekheta, 2005). RWC was also reduced and water deficit increased in roots and leaves of the seedlings of Iris lacteal under $\mathrm{NaCl}$ stress (Wang et al., 2012). In the salt-tolerant 'Astro', the osmotic potential decreased with increasing $\mathrm{NaCl}$ concentrations, while RWC decrease did not take place until $200 \mathrm{mM} \mathrm{NaCl}$ (Hniličková et al., 2017).

The significance of photosynthetic characteristics in salt tolerance species is still discussed and varies according to species (Xu et al., 2011; Saravanavel et al., 2012; Hniličková et al., 2017). Some investigators have shown that $\mathrm{P}_{\mathrm{n}}$ was hardly reduced by salinity and sometimes even enhanced under low salt concentrations (Downton et al., 1985; Dionisio-Sese and Tobita, 2000). Others have shown a distinctive decrease in $P_{n}$ in plants exposed to salinity (Yeo et al., 1985; Plaut, 1987). According to Yeo et al. (1985) and Galme's et al. (2007), salinity did not, initially, reduce $P_{n}$ in the whole plant but only in the older leaves in which sodium accumulated. In salt-tolerant Iris lactea, under salt stress the $\mathrm{P}_{\mathrm{n}}$ lowered, $\mathrm{g}_{\mathrm{s}}$ decreased and $\mathrm{CO}_{2 \text { int }}$ concentration increased, which belonged to the non-stomatal limitation (Wang et al., 2012). The Lens calinaris plants close their stomata which lead to enhanced stomatal resistance (Turan et al., 2007). Stomatal closure is known to be an effective mechanism for economical water utilisation under salt stress and limitation of the harmful salt ions uptake (Hasegawa et al., 2000). The total chlorophyll concentration of Lens calinaris leaves were reduced by increasing the level of $\mathrm{NaCl}$ applied (Turan et al., 2007). In natural conditions, Avicennia germinans tolerates 
a range of salinity, from almost freshwater to up three times seawater. However, its $P_{n}$ is lowered when salt concentration in the soil increases (Sobrado, 1999). In Eruca sativa, TR decreased at the concentration at low salinity level whereas $g_{s}$ and $P_{n}$ decreased at high salinity level (Hniličková et al., 2017). Ashraf and Harris (2013) state that the mechanism of photosynthesis involves various components, including photosynthetic pigments and photosystems, the electron transport system, and $\mathrm{CO}_{2}$ reduction pathways. Any damage at any level caused by a stress factor may reduce the overall photosynthetic capacity of a green plant.

Peanut (Arachis hypogaea L.) is one of the more important grain legumes in tropical cropping systems in Africa, being important to both small and large commercial producers (Nyabyenda, 2005). Grain legumes provide large amounts of high-quality proteins which contain relatively more of the essential amino acids not supplied by cereals in which the content of lysine and trytophan are relativey small (Kay, 1979). Peanut is also useful sources of fat (34-54\%) and very important in crop rotation systems as they help in biological nitrogen fixation (Taiz and Zeiger, 2002). It also contains polyphenols, polyunsaturated and monounsaturated fats, phytosterols and dietary fiber in amounts similar to several tree nuts (Musa, 2010). Efforts to enhance crop yield under salt stress have had a limited success because available knowledge of the mechanisms of salt tolerance has not been completed and also not turned into useful selection of species. Screening plant species for salinity tolerance or genetic potential to develop tolerance are promising approaches for developing salt-tolerant varieties for breeding program. Therefore, this study was undertaken to evaluate the effects of salt stress on plant growth, relative water content, chlorophyll content, stomatal conductance, transpiration rate, photosynthetic rate, yield of photosystem II and the intercellular $\mathrm{CO}_{2}$ concentration of three peanut (Arachis hypogaea L.) varieties.

\section{Materials and Methods}

\section{Plant materials}

Peanut (Arachis hypogaea L.) is a legume crop grown mainly for its edible seeds. As a legume, the peanut belongs to the botanical family of Fabaceae. It is widely grown in the tropics and subtropics, being important to both small and large commercial producers. Peanut plants grow best in light, sandy loam soil with a $\mathrm{pH}$ of 5.9-7. Their capacity to fix nitrogen means that, providing they nodulate properly, peanuts benefit little or not at all from nitrogen-containing fertilizer and they improve soil fertility. Also, the yield of the peanut crop itself is increased in rotations, through reduced diseases, pests and weeds. To develop well, peanut plants need warm weather throughout the growing season. They can be grown with as little as $350 \mathrm{~mm}$ of water, but for best yields need at least $500 \mathrm{~mm}$. Peanut is also useful sources of fat (34-54\%) and very important in crop rotation systems as they help in biological nitrogen fixation (Taiz and Zeiger, 2002). It also contains polyphenols, polyunsaturated and monounsaturated fats, phytosterols and dietary fibber in amounts similar to several tree nuts (Musa, 2010). Peanut is also rich in essential nutriments such as vitamins $B$ and $E$. They also contain about $25 \%$ protein, a higher proportion than in many tree nuts. Seeds of three peanut varieties ('P1184948', 'P244601' and 'Vanda'), provided by the breeding program of the Agronomic Institute for Research and Development of Ghana, Tanzania and Cameroon, respectively, were used in the study.

\section{Plant growth conditions and salt treatments}

The experiment was conducted in the greenhouse and growth chamber of Leibniz Universität Hannover, Germany, from October to November 2017. Seeds of peanut plants were surface sterilized with $70 \%(\mathrm{v} / \mathrm{v})$ ethanol solution for $15 \mathrm{~min}$, then rinsed four times with deionized water. Seeds of each variety were sown in rock-wool cubes $(36 \mathrm{~mm} * 36 \mathrm{~mm} * 40 \mathrm{~mm})$ in the greenhouse at $26{ }^{\circ} \mathrm{C}$ and $55 \%$ of the relative air humidity averaged with deionized water. Eight days after sowing (DAS), when primordial leaves were fully established, seedlings were transplanted into $30-\mathrm{L}$ plastic pots filled with $26 \mathrm{~L}$ of the nutrient solution in the growth chamber. The pots were arranged in a complete randomized design upon styrofoam floating with six 
plants per pot and four replicates per treatment. All plants were fertilized with a modified nutrient solution containing (in $\mathrm{mg} \mathrm{L}^{-1}$ ): $57.7 \mathrm{mg} \mathrm{NO}_{3}, 0.8 \mathrm{mg} \mathrm{NH}_{4}^{+}, 58.4 \mathrm{mg} \mathrm{N}, 115.6 \mathrm{mg} \mathrm{K}, 86.2 \mathrm{mg} \mathrm{Ca}, 12.7 \mathrm{mg} \mathrm{Mg}$ and 18.1 $\mathrm{mg} \mathrm{P}$ (Chen et al., 2015). The $\mathrm{pH}$ value of the nutrient solution was included 5.9-6.2. Throughout the growth period, average day/night temperatures in the growth chamber were $29{ }^{\circ} \mathrm{C} / 23^{\circ} \mathrm{C}$, the relative air humidity averaged $55 \%$, photosynthetic active radiation $200 \mu \mathrm{mol} \mathrm{m}^{-2} \mathrm{~s}^{-1}$ and day/dark $12 \mathrm{~h}$. Thirteen days after seedlings tranfert, the growth chamber experiments (for 3 weeks) were designed to assess the physiological responses of peanut varieties to salt stress, each variety was subjected to $0,40,80$ and $120 \mathrm{mM} \mathrm{NaCl}$ in nutrient solution.

\section{Plant growth parameters}

Plants were harvested 42 DAS. NB, NL and TLA were recorded. Leaves, stems, and roots were separately dried at $85^{\circ} \mathrm{C}$ for $48 \mathrm{~h}$, and their dry weights were determined. The RWC ((leaf FW-leaf DW) ${ }^{*} 100 /$ leaf FW) and TLA $\left(2 / 3^{*}\right.$ length ${ }^{*}$ width ${ }^{*} 0.80^{*}$ total no. of leaves $\left.{ }^{*} 0.662\right)$ were calculated using the methodology described by Kumar et al. (2002). Leaf CHL was determined by chlorophyll meter (Opti-Sciences) CCM-200 PLUS device.

\section{Photosynthetic characteristics}

TR, gs, Pn, PPsII and $\mathrm{CO}_{2 \text { int }}$ concentrations were determined using portable photosynthesis system Li6800 (LiCor Inc, NE, USA) equipped with multiphase flash fluorometer. The light condition was kept to $200 \mu \mathrm{mol} \mathrm{m} \mathrm{s}^{-1}$ and before each measurement, the leaf was left around 5 to $15 \mathrm{~min}$ the leaf get acclimatized to the growth chamber conditions. The leaf temperature was maintained close to the ambient temperature ranking from $28^{\circ} \mathrm{C}$ until the end of the experiment (for 3-week treatments).

\section{Statistical analysis}

The experiment was conducted as a factorial completely randomized design with four $\mathrm{NaCl}$ treatments and three varieties in four replications. All data were statistically analysed using the software XLSAT (STATCON, NY, United States) and first subjected to analyses of variance ANOVA. Statistical differences between treatment means were established using the Fisher LSD test at $\mathrm{p}<0.05$.

\section{Results and Discussion}

\section{Plant growth}

Peanut growth was estimated by measuring LDW, SL, NB, NL and TLA of three varieties plants under four $\mathrm{NaCl}$ concentrations at vegetative stage ( $42 \mathrm{DAS}$ ). There were statistically significant differences among the varieties for all salt concentrations and plant growth parameters. Application of $\mathrm{NaCl}$ treatment led to a significant $(\mathrm{P}<0.05)$ decrease in LDW, SL, NL and TLA of 'Vanda' and 'P244601' compared to untreated plants (Table 1). The effect of salt on plant growth inhibition was notably noted at $120 \mathrm{mM} \mathrm{NaCl}$ in 'P1184948' for LDW, SL and NB (Table 1). The main effect of $\mathrm{NaCl}$ on plant growth parameters was that plants of 'Vanda' and 'P244601' under $40 \mathrm{mM} \mathrm{NaCl}$ remained almost unaffected for LDW, SL, NB and NL and presented significantly increased values for LDW as compared to those of untreated plants (Table 1). A significant two-way interaction between variety and salt treatment was significant $(\mathrm{P}<0.05)$ for LDW and TLA (Table 1). The responses of plants to high soil salinity and the mechanisms of salt tolerance have been discussed in many works published (Munns, 2002; Meguekam et al., 2014; Nouck et al., 2016; Taffouo et al., 2017; Hniličková et al., 2017). In this study, the detrimental effects of salt on 'Vanda' and 'P244601' plant growth parameter above $40 \mathrm{mM} \mathrm{NaCl}$ are the consequence of both a water deficit that results from the relatively high solute concentrations in the soil as well as a stress specific to $\mathrm{Cl}$ and $\mathrm{Na}$, resulting in a wide variety of physiological and biochemical changes that inhibit plant growth and development and disturb photosynthesis, respiration, protein synthesis and nucleic-acid metabolism (Sairam et al., 2002; Mekhadi et al., 
2008; Negrão et al., 2017). This is consistent with the reports that $\mathrm{NaCl}$ reduces the ability of the plant to take up water, and this leads to slow growth and then, when excessive amounts of salt entering the transpiration stream will eventually injure cells in the transpiring leaves and this may further reduce growth (Munns et al., 2006). In this study, the growth inhibition effect of salt in growth parameters studied was significantly $(\mathrm{p}<$ $0.05)$ noted above $40 \mathrm{mM} \mathrm{NaCl}$ in 'Vanda' while the growth of 'P1184948' was significantly $(\mathrm{p}<0.05)$ affected only at $120 \mathrm{mM} \mathrm{NaCl}$ for LDW, SL and NB (Table 1). These results demonstrate that 'Vanda', in common with certain other plant leguminous (e.g. beans), is highly sensitive to salt with severe effects at $50 \mathrm{mM} \mathrm{NaCl}$ (Levitt, 1980; Taffouo et al., 2009). Under salt stress 'P1184948' was observed to have relatively higher tolerance on average of all growth parameters than others (Table 1). Similar observations for plant growth were reported in 'White seed coat' (Taffouo et al., 2010), 'Fleur 11" (Meguekam et al., 2014) and 'Granada' (Taffouo et al., 2017) and described as salt-tolerant varieties. In case of high salinity, oxidative stress occurs due to closure of stomata, interruption of photosynthetic electron transport and disruption of cellular membrane integrity and antioxidative defence systems of plants start work against oxidative damage (Sairam et al., 2002; Mehr et al., 2012).

Table 1. Effect of salt stress on plant growth in peanut varieties at the vegetative stage (42 DAS)

\begin{tabular}{|c|c|c|c|c|c|c|}
\hline Variety & $\begin{array}{l}\text { Treatment } \\
(\mathrm{mM} \mathrm{NaCl})\end{array}$ & $\begin{array}{c}\text { LDW } \\
\left(\text { g plant }^{-1}\right)\end{array}$ & $\begin{array}{c}\mathrm{SL} \\
(\mathrm{cm})\end{array}$ & NL & NB & $\begin{array}{c}\text { TLA } \\
\left(\mathrm{cm}^{2} \text { plant }^{-1}\right)\end{array}$ \\
\hline \multirow[t]{4}{*}{ 'Vanda' } & 0 & $3.20 \pm 0.00 \mathrm{~b}$ & $14.60 \pm 0.24 \mathrm{a}$ & $5.67 \pm 0.10 b$ & $1.58 \pm 0.13 b$ & $310.90 \pm 0.23 a$ \\
\hline & 40 & $3.53 \pm 1.02 \mathrm{a}$ & $14.48 \pm 0.01 \mathrm{a}$ & $5.67 \pm 0.10 b$ & $1.58 \pm 0.10 \mathrm{~b}$ & $260.38 \pm 0.03 b$ \\
\hline & 80 & $1.83 \pm 0.55 \mathrm{~d}$ & $14.25 \pm 0.06 \mathrm{~b}$ & $5.44 \pm 0.00 c$ & $1.58 \pm 0.13 b$ & $226.88 \pm 0.10 \mathrm{f}$ \\
\hline & 120 & $1.20 \pm 0.21 \mathrm{f}$ & $13.84 \pm 0.02 \mathrm{~b}$ & $5.00 \pm 0.19 \mathrm{e}$ & $0.83 \pm 0.07 \mathrm{f}$ & $212.03 \pm 0.16 \mathrm{~g}$ \\
\hline \multirow[t]{4}{*}{ 'P1 244601' } & 0 & $2.09 \pm 0.30 \mathrm{c}$ & $14.37 \pm 0.33 \mathrm{~b}$ & $5.11 \pm 0.13 \mathrm{~d}$ & $1.25 \pm 0.11 \mathrm{~d}$ & $199.73 \pm 0.18 \mathrm{i}$ \\
\hline & 40 & $2.14 \pm 0.25 c$ & $14.03 \pm 0.21 \mathrm{~b}$ & $5.00 \pm 0.08 \mathrm{e}$ & $1.33 \pm 0.16 c$ & $164.85 \pm 0.01 \mathrm{j}$ \\
\hline & 80 & $1.79 \pm 0.41 \mathrm{~d}$ & $13.83 \pm 0.13 c$ & $4.89 \pm 0.03 \mathrm{f}$ & $1.33 \pm 0.16 c$ & $158.69 \pm 0.05 j$ \\
\hline & 120 & $1.54 \pm 0.28 \mathrm{e}$ & $11.70 \pm 0.67 \mathrm{de}$ & $4.33 \pm 0.23 \mathrm{~g}$ & $0.33 \pm 0.04 \mathrm{~g}$ & $146.78 \pm 0.12 \mathrm{k}$ \\
\hline \multirow[t]{4}{*}{ 'P1 184948’ } & 0 & $3.14 \pm 0.20 \mathrm{~b}$ & $12.23 \pm 0.18 \mathrm{~d}$ & $6.11 \pm 0.19 a$ & $1.08 \pm 0.01 \mathrm{e}$ & $202.76 \pm 0.13 \mathrm{~d}$ \\
\hline & 40 & $3.17 \pm 0.66 \mathrm{~b}$ & $11.90 \pm 0.04 \mathrm{~d}$ & $6.11 \pm 0.12 \mathrm{a}$ & $1.75 \pm 0.32 \mathrm{a}$ & $236.04 \pm 0.04 \mathrm{e}$ \\
\hline & 80 & $2.27 \pm 0.63 c$ & $11.84 \pm 0.01 \mathrm{~d}$ & $6.11 \pm 0.19 a$ & $1.17 \pm 0.06 \mathrm{~d}$ & $243.93 \pm 0.08 c$ \\
\hline & 120 & $1.61 \pm 0.76 \mathrm{e}$ & $11.25 \pm 0.24 \mathrm{e}$ & $6.11 \pm 0.11 \mathrm{a}$ & $0.25 \pm 0.03 \mathrm{~h}$ & $227.34 \pm 0.05 \mathrm{~h}$ \\
\hline \multicolumn{7}{|c|}{ Two-way ANOVA results } \\
\hline \multicolumn{2}{|c|}{ Variety $(\mathrm{V})$} & $*$ & * & * & * & * \\
\hline \multicolumn{2}{|c|}{ Salt treatment $(S)$} & ** & * & * & * & ** \\
\hline \multicolumn{2}{|c|}{ Interaction VX S } & * & NS & NS & NS & * \\
\hline
\end{tabular}

Values shown are means $(\mathrm{n}=4) \pm S D$, within columns, means followed by different letter are significantly different $(\mathrm{p}$ $<0.05) .{ }^{* *},{ }^{*}$ significant at 1 and $5 \%$ probability levels, respectively, NS not significant. Abbreviations: LDW, Leaf dry weight; SL, Shoot length; NB, number of branches; TLA, Total leaf area.

\section{Leaf relative water content}

In this study, the depressive effect of salt on RWC was recorded at $120 \mathrm{mM} \mathrm{NaCl}$ in peanut leaves of all varieties (Figure 1). Similar results were reported by El-Bassiouny and Bekheta (2005), Wang et al. (2012) and Taffouo et al. (2017) with wheat, pepper and Iris lacteal plants, respectively. Water deficit causes a leaf turgor decrease, further causing stomata closure and decreases of stomatal conductance; one of the factors limiting photosynthesis rate (Chaves et al., 2009). RWC was also reduced and water deficit increased in roots and leaves of the seedlings of Iris lacteal under $\mathrm{NaCl}$ stress (Wang et al., 2012). In the salt-tolerant 'Astro', the osmotic potential decreased with increasing $\mathrm{NaCl}$ concentrations, while RWC decrease did not take place until 200 $\mathrm{mM} \mathrm{NaCl}$ (Hniličková et al., 2017). According to Munns (2002), salinity reduces the ability of plants to take up water and this quickly causes reduction in growth rate, along with a suite of metabolic changes. There are two phases growth response to salinity (Munns, 1993). The first phase of growth reduction is quickly apparent, and is due to the salt outside the roots. It is essentially a water stress or osmotic phase for which there is 
surprisingly little genotypic variation. The growth reduction is presumably regulated by hormonal signals coming from the roots. Then there is a second phase of growth reduction which take time to develop, and results from internal injury. It is due to salts accumulating in transpiring leaves to excessive levels, exceeding the ability of the cells to compartmentalize salts in the vacuole. This will inhibit growth of the younger leaves by reducing the supply of carbohydrates to the growing cells.

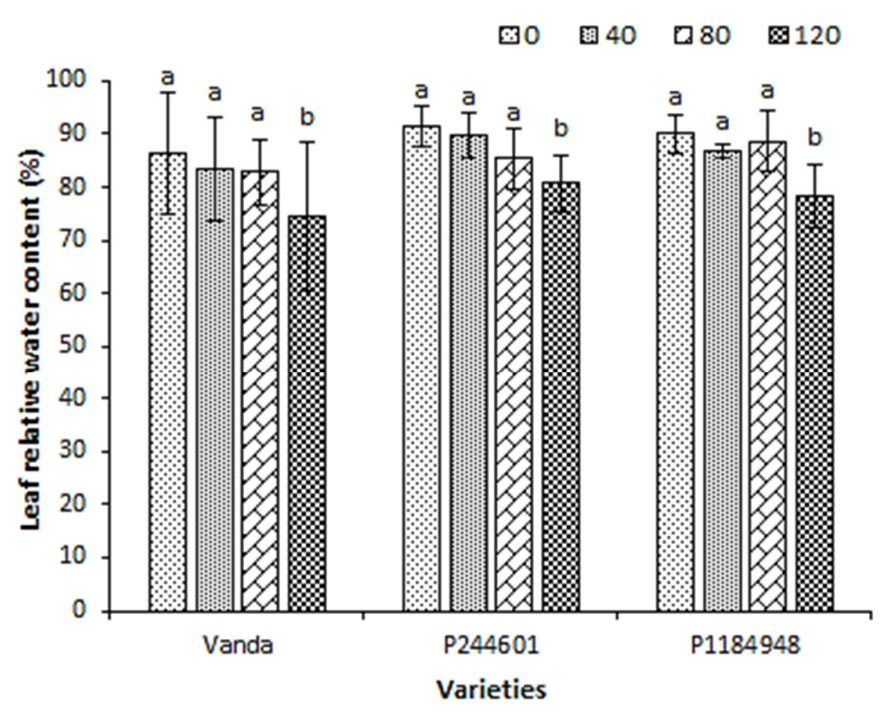

Figure 1. Effect of salt stress on leaf relative water content in peanut varieties at vegetative stage (42 DAS)

Bars are means $(n=4) \pm S D$. Means followed by different letter are significantly different $(\mathrm{p}<0.05)$

\section{Chlorophyll concentrations}

In this study, salinity increased the leaf CHL content in moderately-tolerant 'P244601' and salt-tolerant 'P1184948' at $80 \mathrm{mM} \mathrm{NaCl}$ compared to salt sensitive 'Vanda' and untreated plants (Figure 2). The depressive effect of salt on leaf CHL content in peanut plants was recorded at $120 \mathrm{mM} \mathrm{NaCl}$ (Figure 2). This effect of salt was attributed to a salt-induced weakening of protein-pigment-lipid complex (Strogonov et al., 1970) or increased chlorophyllase enzyme activities (Stivsev et al., 1973). The decreased in chlorophyll content under salt stress is a commonly reported phenomenon and in various studies, because of its adverse effects on membrane stability (Hajer et al., 2006; Meguekam et al., 2014). Similar results were reported by El-Iklil et al. (2002), Turan et al. (2007) and Taffouo et al. (2017) with tomato, lentil and pepper plants, respectively.

\section{Photosynthetic characteristics}

The significance of photosynthetic characteristics $\left(\mathrm{P}_{\mathrm{n}}, \mathrm{g}_{\mathrm{s}}, \mathrm{TR}\right.$, ФPsII and $\mathrm{CO}_{2 \text { int }}$ concentration) in salt tolerance species is still discussed and varies according to species. In the present study, the presence of $\mathrm{NaCl}$ resulted in a significant decrease in $P_{n}$ in 'Vanda' and 'P244601' compared to untreated plants (Figure 3A and B). On the contrary, a significant decrease in $P_{n}$ was found only after one week in salt-tolerant 'P1184948' (Figure 3C). Salt induced reduction of $\mathrm{P}_{\mathrm{n}}$ has been previously reported in a number of species (Sobrado, 1999; Lawlor and Cornic, 2002; Hniličková, 2017). According to Munns et al. (2006) and Chaves et al. (2009), photosynthesis is the primary processes to be affected by salinity and it also varies according duration of the stress as well as with the leaf age (Galme's et al., 2007). This decrease was related to decline in leaf CHL content in all varieties at $120 \mathrm{mM} \mathrm{NaCl}$ (Figure 2). CHL, one of the most important pigments in photosynthesis, is not only the main pigments of energy absorption and transfer, but also essential for electron transfer (Hajer et al., 2006). In this experiment, leaves from untreated plants grown without $\mathrm{NaCl}$ addition did not show any 
symptoms of necrosis, chlorosis or leaf tissue damage. This is contrary to results of salt-sensitive 'Vanda' that show anomalous leaf development and poor growth.

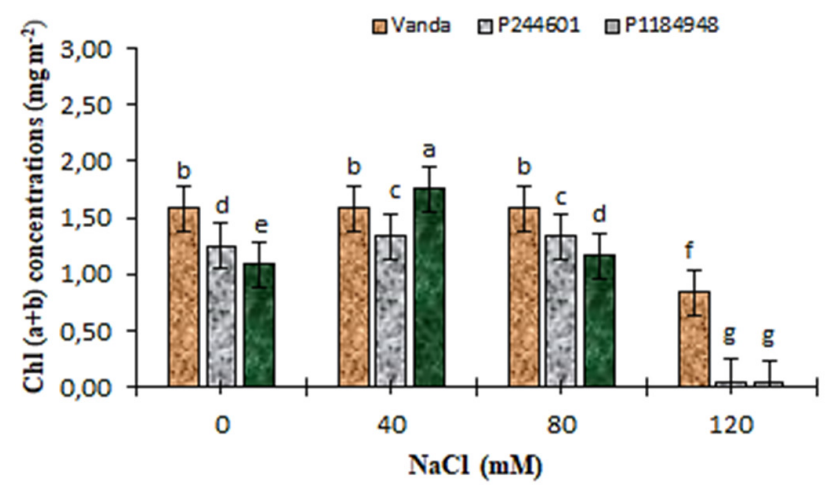

Figure 2. Effect of salt stress on chlorophyll concentrations in peanut varieties at vegetative stage (42 DAS). Bars are means $(n=4) \pm S D$. Means followed by different letter are significantly different $(\mathrm{p}<0.05)$
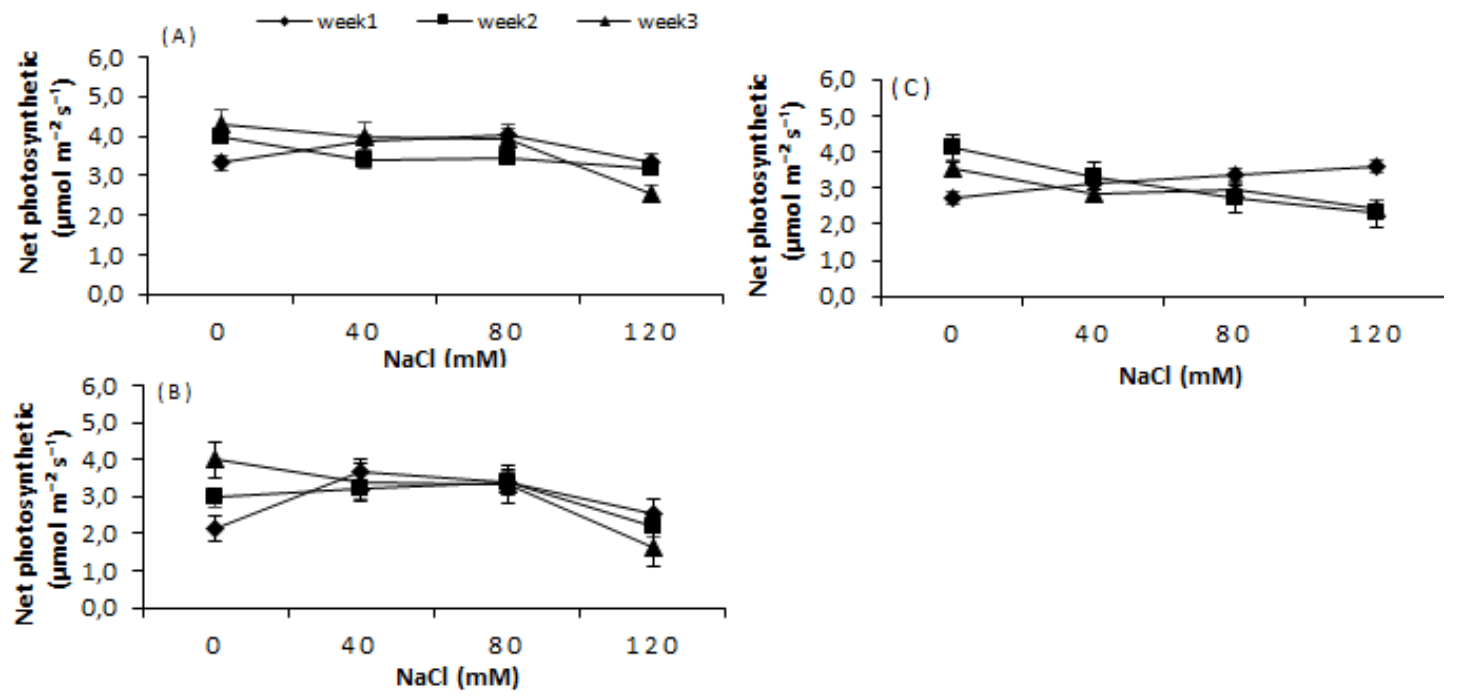

Figure 3. Effect of salt stress on net photosynthetic of leaves in peanut varieties at the vegetative stage ( 42 DAS)

'Vanda' (A), 'P244601' (B) and 'P1184948' (C). Bars are means (n=4) \pm SD

The changes in $\mathrm{P}_{\mathrm{n}}$ of 'Vanda' and 'P244601' may result from the closure of stomata induced by osmotic stress, or from salt damaging of photosynthesic apparatus or other metabolic processes (Sobrado, 1999). In the present study, different $\mathrm{NaCl}$ levels supply had significant effects on $\mathrm{g}_{\mathrm{s}}$ in all peanut varieties (Figure $4 \mathrm{~A}, \mathrm{C}$ and D). Application of $\mathrm{NaCl}$ treatment led to a significant $\left(\mathrm{p}<0.05\right.$ decrease in $\mathrm{g}_{\mathrm{s}}$ of all varieties at $40 \mathrm{mM}$ $\mathrm{NaCl}$ compared to untreated plants. The highest depressive effect was detected in $\mathrm{g}_{\text {s }}$ of 'Vanda' while the lowest were recorded in $\mathrm{g}_{s}$ of salt tolerant 'P1184948' at high salinity level (Figure 4A, B and C). Similar observations were reported by Sobrado (1999) and Acosta-Motos et al. (2015) with Avicennia germinans and Myrtus communis. It has been reported that salinity affects plant physiology through changes of water and ionic status in the cells because of ionic imbalance due to excessive accumulation of $\mathrm{Na}$ and $\mathrm{Cl}$ and reduced uptake of other mineral nutrients, such as $\mathrm{K}, \mathrm{Ca}$ and $\mathrm{Mg}$ (Hasegawa et al., 2000). Water deficit causes a leaf turgor decrease, further causing stomata closure and decreases of $g_{s}$; one of the factors limiting $P_{n}$ (Chaves et al., 2009). According to Sairam et al. (2002) and Mehr et al. (2012), in case of high salinity, oxidative stress occurs due to 
closure of stomata, interruption of photosynthetic electron transport and disruption of cellular membrane integrity and antioxidative defense systems of plants start work against oxidative damage (Sairam et al., 2002; Mehr et al., 2012).
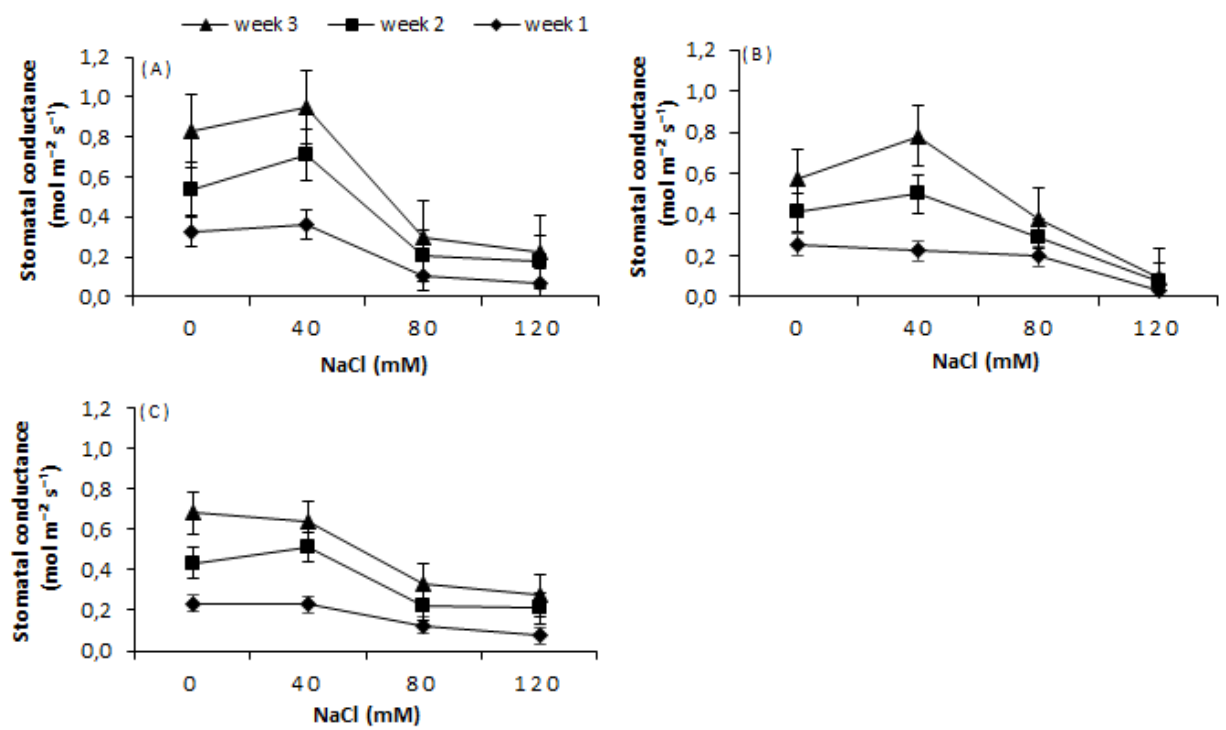

Figure 4. Effect of salt stress on stomatal conductance in peanut varieties at the vegetative stage (42 DAS) 'Vanda' (A), 'P244601' (B) and 'P1184948' (C). Bars are means ( $\mathrm{n}=4) \pm$ SD

Means of the TR in leaves of the peanut varieties (42 DAS) are depicted in Figure 5A, B and C. TR in leaves of all varieties of peanut was affected by different $\mathrm{NaCl}$ levels supply (Figure $5 \mathrm{~A}, \mathrm{~B}$ and $\mathrm{C}$ ). According to Asch (1996), environmental factors had some effects on transpiration among rice varieties subjected to salt stress. The main effect of $\mathrm{NaCl}$ on TR under salt stress showed significant $(\mathrm{P}<0.05)$ decreases as compared to control plants (Figure 5A, B and C).) This is consistent with the reports that $\mathrm{NaCl}$ reduces the ability of the plant to take up water, and this leads to slow growth; then when excessive amounts of salt entering the transpiration stream will eventually injure cells in the transpiring leave and this may further reduce growth (Munns, 2002). Water deficit causes a leaf turgor decrease, further causing stomata closure and decreases $\mathrm{g}_{\text {s; }}$; one of the factors limiting $P_{n}$ (Chaves et al., 2009). Water transpiration drives the water uptake by the roots and transport until the leaves. The amount of water lost is regulate by opening and closing stomata plants, with sacrificing $\mathrm{CO}_{2}$ uptake, when the environmental conditions are unfavourable (Hniličková et al., 2017).

Enhanced $\mathrm{NaCl}$ concentration led to a significant $(\mathrm{P}<0.05)$ increase in ФPSII of salt-tolerant 'P1184948' compared to 'Vanda', 'P244601' and untreated plants (Figure 6A, B and D). These results are consistent with the results obtained by Lu and Vonshak (2002) in halophyte Suaeda salsa. According to Ashraf and Harris (2013); Chen et al. (2015), under the salt stress the $P_{n}, g_{s}$ and DPSII of tolerant species were significantly increased compared with the untreated plants. Increased of $\mathrm{NaCl}$ concentration could contribute to create a water potential in the cells which would rather guarantee water availability for physiological function for the plant (Taffouo et al., 2017). In this study, the slightly decline in ФPSII in salt-sensitive 'Vanda' and moderately-tolerant 'P244601' during their exposure to salt stress (Figure 6A, B and D) could be mainly be due to the synthesis of chlorophyllase which destroys the produced chlorophyll (Meguekam et al., 2014) or to the inhibition of the nitrogen absorption which is an essential in the chlorophyll atom (Paul and Lade, 2014) and to orientation of the photosynthetic activity towards the production of resistance proteins; knowing that, in both crop plants, chemical energy expended in a number of metabolic processes derived from the photosynthetic process (Pan et al., 2012; Ashraf et al., 2013); lipid metabolism (Paul and Lade, 2014) or maintain a relatively high $\mathrm{Na}$ concentration in their shoots to developed mechanism for salinity tolerance 
(Munns et al., 2016; Zaki and Yokoi, 2016). Enhanced salinity provokes changes in the photosynthetic apparatus, by affecting both its structure and function ( $\mathrm{Lu}$ and Vonshak, 2002).

In the present study, $\mathrm{CO}_{2 \text { int }}$ concentrations of leaves were significantly $(\mathrm{P}<0.05)$ reduced with increasing salinity in all varieties (Figure 7A, B and C). These results corroborate the findings of Sobrado (1999) with Avicennia germinans, Turan et al. (2007) with Lens calinaris but they contradict those of Asch et al. (2000) with Oryza sativa plants who reported that salinity increases $\mathrm{CO}_{2}$ assimilation but reduces growth in field-grown. The highest decrease of $\mathrm{CO}_{2 \text { int }}$ concentrations was detected in salt-sensitive 'Vanda' while the lowest was recorded in salt-tolerant ' $\mathrm{P} 1184948$ ' at high salinity level $(120 \mathrm{mM} \mathrm{NaCl})$ compared to moderatelytolerant 'P244601' and untreated plants (Figure 7A, B and C). The decreased $\mathrm{CO}_{2 \text { int }}$ concentration availability observed in leaves of these varieties, mainly in 'Vanda' can be caused by the diffusion limitations through the stomata and the mesophyll (Flexas et al., 2007; Bacha et al., 2017) or the alterations of photosynthetic metabolism (Law and Cornic, 2002). It is stated that high level of $\mathrm{Na}$ inhibits $\mathrm{Ca}$ and $\mathrm{K}$ absorption, which results in a $\mathrm{N} / \mathrm{K}$ antagonism (Taffouo et al., 2009) and $\mathrm{P}_{\mathrm{n}}$ is affected strongly by $\mathrm{NaCl}$ saline conditions, which is related directly to the closure of stomata as well as to low $\mathrm{CO}_{2 \text { int }}$ levels (Turan et al., 2007).
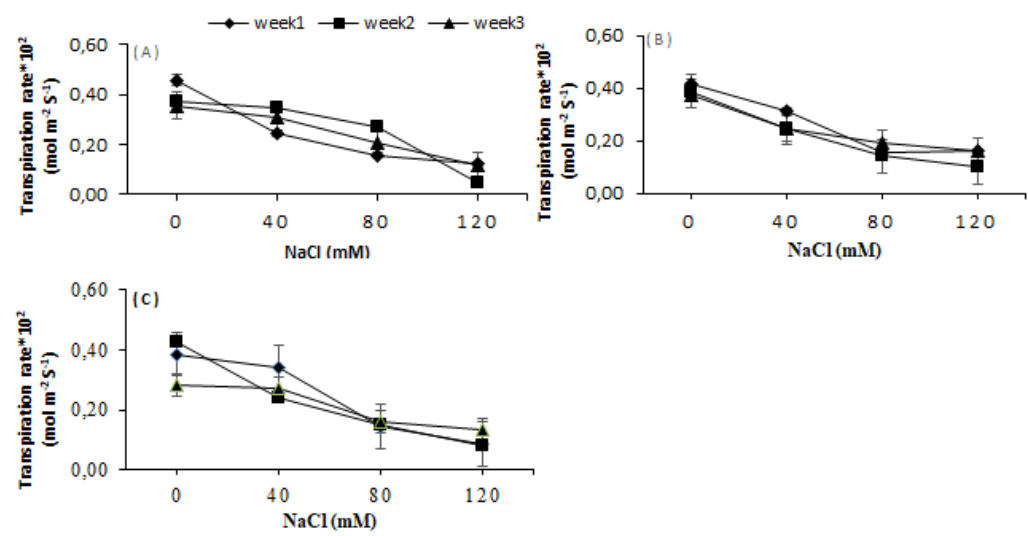

Figure 5. Effect of salt stress on transpiration rate of leaves in peanut varieties at the vegetative stage (42 DAS)

'Vanda' (A), 'P244601' (B) and 'P1184948' (C). Bars are means (n=4) \pm SD
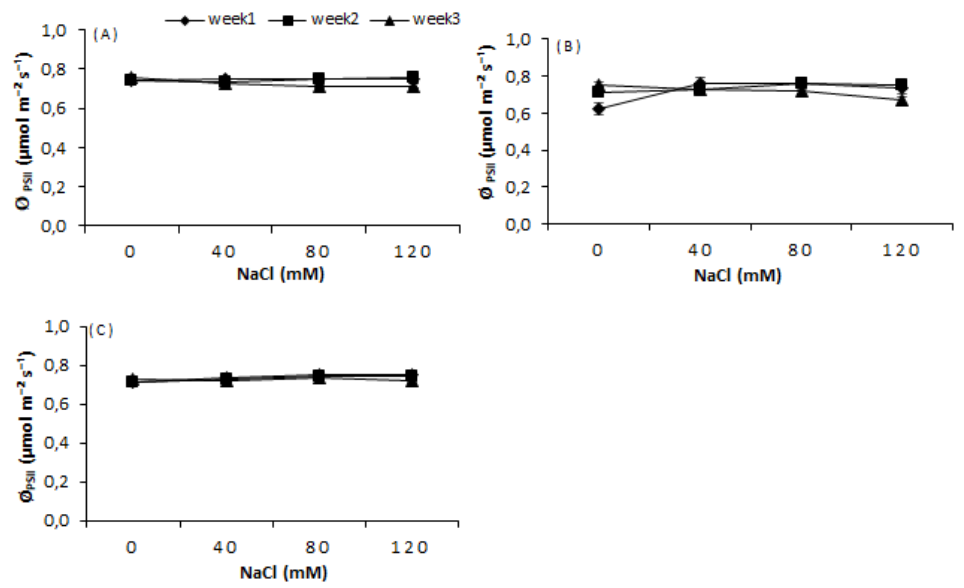

Figuri 6. Effect of salt stress on the yield of photosystem II in peanut varieties at the vegetative stage ( 42 DAS)

'Vanda' (A), 'P244601' (B) and 'P1184948' (C). Bars are means ( $\mathrm{n}=4) \pm S D$ 

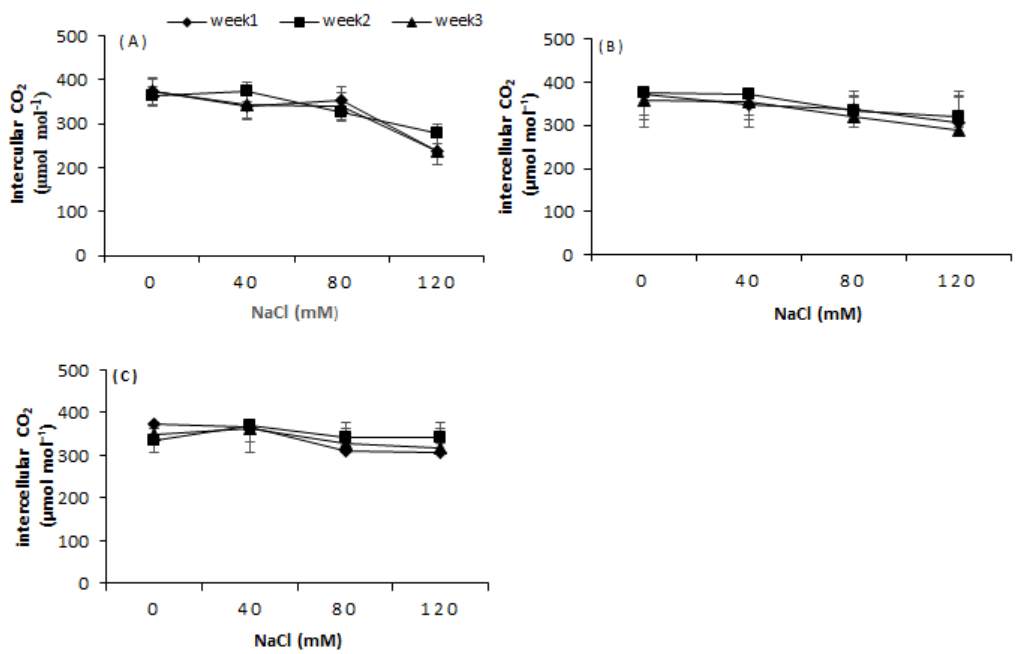

Figure 7. Effect of salt stress on the intercellular $\mathrm{CO}_{2}$ concentration in peanut varieties at the vegetative stage (42 DAS)

'Vanda' (A), 'P244601' (B) and 'P1184948' (C). Bars are means ( $\mathrm{n}=4) \pm S D$

\section{Conclusions}

Salt stress in peanut affected all monitored parameters. Application of $\mathrm{NaCl}$ treatment led to a significant decrease in LDW, SL, NL, TLA, $\mathrm{P}_{n}, \mathrm{~g}_{s}, \mathrm{TR}$ and $\mathrm{CO}_{2 \text { int }}$ concentrations of salt-sensitive 'Vanda' and moderately-tolerant 'P244601' compared to untreated plants while the plant growth inhibition was notably noted at $120 \mathrm{mM} \mathrm{NaCl}$ in salt-tolerant 'P1184948' for LDW, SL and NB. The highest depressive effect was detected in $\mathrm{g}_{\mathrm{s}}$ of salt-sensitive 'Vanda' while the lowest were recorded in $\mathrm{g}_{\mathrm{s}}$ of salt-tolerant 'P1184948' at high salinity level. Enhanced $\mathrm{NaCl}$ concentrations led to a significant increase in ФPSII of 'P1184948' compared to 'Vanda', 'P244601' and untreated plants. LeafCHL content was significantly increased in moderately-tolerant 'P244601' and salt-tolerant 'P1184948' at $80 \mathrm{mM} \mathrm{NaCl}$ compared to salt sensitive 'Vanda' and untreated plants. The depressive effect of salt on RWC was recorded at $120 \mathrm{mM} \mathrm{NaCl}$ in peanut leaves of all varieties. Under salt stress 'P1184948' was observed to have relatively higher tolerance on average of all growth and physiological traits than 'Vanda' and 'P244601' suggesting that it could be grown in salt-affected soils. This study conducted in peanut varieties provides additional information on the mechanisms of salt tolerance and may be helpful for breeding program.

\section{Authors' Contributions}

All authors read and approved the final manuscript.

\section{Acknowledgements}

This work was financially supported by two months research stay at the University of Leibniz in Hannover under the DAAD scholarship program of 2017. We thank Mrs Ilona Napp for her technical assistance during this experimental period. 


\section{Conflict of Interests}

The authors declare that there are no conflicts of interest related to this article.

\section{References}

Abogadallah GM, Serag M, Quick WP (2010). Fine and coarse regulation of reactive oxygen species in the salt tolerant mutants of barnyard grass and their wild type parents under salt stress. Physiologia Plantarum 138:60-73. https://doi.org/10.1111/j.1399-3054.2009.01297.x

Acosta-Motos JR, Diaz-Vivancosb P, Álvarez S, Fernández-García N, Sánchez-Blanco MJ, Hernández JA (2015). NaClinduced physiological and biochemical adaptative mechanisms in the ornamental Myrtus communis L. plants. Journal of Plant Physiology 183:41-51. https://doi.org/10.1016/j.jplph.2015.05.005

Asch F (1996). Air humidity effects on transpiration differ among rice varieties subjected to salt stress. In: West Africa rice development association. Annual Report 1995. Warda, Bouake, Ivoiry Coast pp 97-98.

Asch F, Dingkuhn M, Dorffling K (2000). Salinity increases CO2 assimilation but reduces growth in field-grown, irrigated rice. Plant and Soil 1:218. https://doi.org/10.1023/A:1014953504021

Ashraf M (2009). Biotechnological approach of improving plant salt tolerance using antioxidants as markers. Biotechnology Advances 27:84-93. https://doi.org/10.1016/j.biotechadv.2008.09.003

Ashraf MHPJC, Harris PJ (2013). Photosynthesis under stressful environments: An overview. Photosynthetica 51:163190. https://doi.org/10.1007/s11099-013-0021-6

Azooz MM, Ismail AM, Abou-Elhamd MF (2009). Growth, lipid peroxidation and antioxidant enzyme activities as a selection criterion for the salt tolerance of three maize cultivars grown under salinity stress. International Journal of Agriculture and Biology 11:21-26.

Bacha H, Tekaya M, Drine S, Guasmi F, Touil L, Enneb H, ... Ferchichi A (2017). Impact of salt stress on morphophysiological and biochemical parameters of Solanum lycopersicum cv. Microtom leaves. South African Journal of Botany 108:3644-369. https://doi.org/10.1016/jsajb.2016.08.018

Chaves MM, Flexas J, Pinheiro C (2009). Photosynthesis under drought and salt stress: regulation mechanisms from whole plant to cell. Annals of Botany 103(4):551-560. https://doi.org/10.1093/aob/mcn125

Chen TW, Kahlen K, Stützel H (2015). Disentangling the contributions of osmotic and ionic effects of salinity on stomatal, mesophyll, biochemical and light limitations to photosynthesis. Plant Cell and Environment 38:15281542. https://doi.org/10.1111/pce.12504

Chen TW, Nguyen TMN, Kahlen K, Stützel H (2015). Quantification of the effects of architectural traits on dry mass production and light interception of tomato canopy under different temperature regimes using dynamic functional-structural plant model. Journal of Experimental Botany 65:6399-6410. https://doi.org/10.1093/jxb/eru356

Dionisio-Sese ML, Tobita S (2000). Effects of salinity on sodium content and photosynthetic responses of rice seedlings differing in salt tolerance. Journal of Plant Physiology 157(1):54-58. https://doi.org/10.1016/S0176$1617(00) 80135-2$

Downton WJS (1977). Photosynthesis in salt-stressed grapevines. Australian Journal of Plant Physiology 4:183-192. https://doi.org/10.1071/PP9770183

El-Bassiouny HMS, Bekheta M (2005). Effect of different salinity levels on polyamine contents (Put, Spd, Spm) of two wheat cultivars ('Giza 168' and 'Gimeza 9'). International Journal of Agriculture and Biology 7(3):366.

El-Iklil Y, Karrou M, Benichou M (2000). Salt stress effect on epinasty in relation to ethylene production and water relations in tomato. Agronomie 20:399-406. https://doi.org/10.1051/agro:2000136f

Flexas J, Diaz-Espejo A, Galmès J, Kaldenhoff R, Medrano H, Ribas-Carbo M (2007). Rapid variations of mesophyll conductance in response to change in $\mathrm{CO}_{2}$ concentration around leaves. Plant, Cell and Environment 30:12841298. https://doi.org/10.1111/j.1365-3040.2007.01700.x

Galmes J, Medrano H, Flexas J (2007). Photosynthetic limitations in response to water stress and recovery in Mediterranean plants with different growth forms. New Phytologist 175:81-93. https://doi.org/10.1111/j.14698137.2007.02087.x 
Hajer AS, Malibari AA, Ai-Zahrani HS, Almaghrabi OA (2006). Responses of three tomato cultivars to seed water salinity: Effect of salinity on the seedling growth. African Journal of Biotechnology 5(10):855-861.

Hasegawa PM, Bressan RA, Zhu JK, Bohnert HJ (2000). Plant cellular and molecular responses to high salinity. Annual Review of Plant Physiology and Plant Molecular Biology 51:463-499. https://doi.org/10.1146/annurev.arplant.51.1.463

Hniličková H, Hnilička F, Martinková J, Kraus K (2017). Effects of salt stress on water status, photosynthesis and chlorophyll fluorescence of rocket. Plant Soil and Environment 63:362-367. https://doi.org/10.17221/398/2017-PSE

Kay ED (1979). Food legumes. Tropical Products Institutes, London, Digest.

Kumar N, Krishnamoorty V, Nalina L, Soorianathasundharam K (2002). A new factor for estimating total leaf area in banana. Info Musa 11:42-43.

Lawlor DW, Cornic G (2002). Photosynthetic carbon assimilation and associated metabolism in relation to water deficits in higher plants. Plant, Cell and Environment 25:275-294. https://doi.org/10.1046/j.0016-8025.2001.00814.x

Levitt J (1980). Responses of plant to environmental stress. Vol. II: Water, radiation, salt and other stresses. United Kingdom. Edition Academic Press. London pp 395-434.

Lu C, Vonshak A (2002). Effects of salinity stress on photosystem II function in cyanobacterial Spirulina platensis cells. Physiologia Plantarum 114:405-413. https://doi.org/10.1034/j.1399-3054.2002.1140310.x

Meguekam TL, Taffouo VD, Grigore MN, Zamfirache MN, Youmbi E, Amougou A (2014). Differential responses of growth, chlorophyll content, lipid peroxidation and accumulation of compatible solutes to salt stress in peanut (Arachis hypogaea L.) cultivars. African Journal of Biotechnology 13(50):4577-4585. https://doi.org/10.5897/AJB2014.14248

Mehr ZS, Khajeh H, Bahabadi SE, Sabbagh SK (2012). Changes on proline, phenolic compounds and activity of antioxidant enzymes in Anethum graveolens L. under salt stress. International Journal of Agronomy and Plant Production 3:710-715.

Mekhaldi A, Benkhelifa M, Belkhodja M (2008). The effect of salinity on gas exchange on different development stages of mung bean (Vigna radiata L. Wilczeck). International Journal of Botany 4(3):269-275. https://doi.org/10.3923/ijb.2008.269.275

Mirza H, Khalid RH, Kamrun N, Hesham FA (2019). Plant abiotic stress: tolerance agronomic, molecular and biotechnological approaches. Springer.

Munns R (1993). Physiological processes limiting plant growth in saline soil: some dogmas and hypothesis. Plant, Cell and Environment 16:15-24. https://doi.org/10.1111/j.1365-3040.1993.tb00840.x

Munns R (2002). Comparative physiology of salt and water stress. Plant Cell and Environment 25:239-250. https://doi.org/10.1046/j.0016-8025.2001.00808.x

Munns R, Gilliham M (2015). Salinity tolerance of crops-what is the cost? New Physiologist 208:668-673. https://doi.org/10.1111/nph.13519

Munns R, James RA, Läuchli A (2006). Approaches to increasing the salt tolerance of wheat and other cereals. Journal of Experimental Botany 57:1025-1043. https://doi.org/10.1093/jxb/erj100

Musa OM (2010). Some nutritional characteristics of kernel and oil of peanut (Arachis hypogaea L.). Journal of Oleo Science 59(1):1-5. https://doi.org/10.5650/jos.59.1

Negrão S, Schmöckel SM, Tester M (2017). Evaluating physiological responses of plants to salinity stress. Annals of Botany 119:1-11. https://doi.org/10.1093/aob/mcw191

Nouck AE, Taffouo VD, Tsoata E, Dibong DS, Nguemezi ST, Gouado I, Youmbi E (2016). Growth, biochemical constituents, micronutrient uptake and yield response of six tomato (Lycopersicum esculentum L.) cultivars grown under salinity stress. Journal of Agronomy 15:58-67. https://doi.org/10.3923/ja.2016.58.67

Nyabyenda P (2005). Cultivated crops in tropical highland area in Africa. Gembloux Agronomic Press.

Pan J, Lin S, Woodbury NW (2012). Bacteriochlorophyll excited state quenching pathways in bacterial reaction centers with the primary donor oxidized. The Journal of Physical Chemistry Biology 116:2014-2022. https://doi.org/10.1021/jp212441b

Paul D, Lade H (2014). Plant-growth-promoting rhizobacteria to improve crop growth in saline soils. Agronomy and Sustainable Development 34:737-752. https://doi.org/10.1007/s13593-014-0233-6f

Plaut ZVI (1987). Response of photosynthesis to water and salt stress-similarities and dissimilarities. In: Kreeb KH, Richter H, Hinckley TM (Eds). Structural and functional responses to environmental stresses: water shortage. 
Proceedings of Symposium of XIV International Botanical Congress, Berlin, Germany 24 July to $1^{\text {st }}$ August 1987.

Sairam RK, Rao KV, Srivastava GC (2002). Differential response of wheat genotypes to long term salinity stress in relation to oxidative stress, antioxidant activity and osmolytes concentration. Plant Science 163:1037-1046. https://doi.org/10.1.1.831.5301\&rep=rep1\&type $=p d f$

Saravanavel R, Ranganathan R, Anantharaman P (2011). Effect of sodium chloride on photosynthetic pigments and photosynthetic characteristics of Avicennia officinalis seedlings. Recent Research in Science and Technology 3:177-180.

Sivtsev MV, Ponomareva SA, Kuznetsova EA (1973). Effect of salinization and an herbicide on chlorophyllase activity in tomato leaves. Fiziologiya Rastenii 20(1):62-65.

Sobrado MA (1999). Leaf photosynthesis of the mangrove Avicennia germinans as affected by $\mathrm{NaCl}$. Photosynthetica 36(4):547-555. https://doi.org/10.1023/A:1007092004582

Strogonov BP, Kabanov VV, Lapina LP, Prykhodko LS (1970). Structure and function of plant cells under salinity conditions. Nauka Publishing House Moscow.

Taffouo VD, Kouamou JK, Ngalangue LMT, Ndjeudji B, Akoa A (2009). Effects of salinity stress on growth, ions partitioning and yield of some cowpea (Vigna unguiculata L. Walp.) cultivars. International Journal of Botany 5:135-145. https://doi.org/10.3923/ijb.2009.135.143

Taffouo VD, Meguekam L, Akoa A, Ourry A (2010). Salt stress effects on germination, plant growth and accumulation of metabolites in five leguminous plants. Journal of Agricultural Science and Technology 4(2):1939-1250.

Taffouo VD, Nouck AE, Nyemene KP, Tonfack B, Meguekam TL, Youmbi E (2017). Effects of salt stress on plant growth, nutrient partitioning, chlorophyll content, leaf relative water content, accumulation of osmolytes and antioxidant compounds in pepper (Capsicum annuum L.) cultivars. Notulae Botanicae Horti Agrobotanici ClujNapoca 45(2):481-490. https://doi.org/10.15835/nbha45210928

Taiz H, Zeiger E (2002). Plant physiology, 3rd Edition. Snauer Associates, Inc.

Turan MA, Turmen N, Taban N (2007). Effect of $\mathrm{NaCl}$ on stomatal resistance and proline, chlorophyll, $\mathrm{Na}, \mathrm{Cl}$ and $\mathrm{K}$ concentrations of lentils plants. Journal of Agronomy 6(2):378-381. https://doi.org/10.3923/ja.2007.378.381

Wang W-Y, Yan X-F, Jiang Y, Qu B, Xu Y-F (2012). Effects of salt stress on water content and photosynthetic characteristics in Iris lactea var. chinensis seedlings. Middle-East Journal of Scientific Research 12(1):70-74. https://doi.org/10.5829/idosi.mejsr.2012.12.1.1660

Waterman PG, Mole S (1994). Analysis of phenolic plant metabolites. Oxford, London, Bluckwell Scientific Publications. Xu Y, Wang L, Wang W, Song Z, Wang D (2009). Research on physiological characteristics of salt resistance in Iris lactea var. chinensis. Bulletin of Botanical Research 29(5):549-552.

Yeo AR, Caporn SJM, Flowers TJ (1985). The effects of salinity upon photosynthesis in rice (Oryza sativa): gas exchange by individual leaves in relation to their salt content. Journal of Experimental Botany 36(169):1240-1248. http://dx.doi.org/10.1093/jxb/36.8.1240
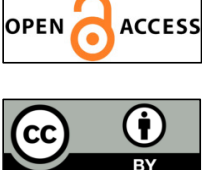

The journal offers free, immediate, and unrestricted access to peer-reviewed research and scholarly work. Users are allowed to read, download, copy, distribute, print, search, or link to the full texts of the articles, or use them for any other lawful purpose, without asking prior permission from the publisher or the author.

License - Articles published in Notulae Botanicae Horti Agrobotanici Cluj-Napoca are Open-Access, distributed under the terms and conditions of the Creative Commons Attribution (CC BY 4.0) License. (c) Articles by the authors; UASVM, Cluj-Napoca, Romania. The journal allows the author(s) to hold the copyright/to retain publishing rights without restriction. 